\title{
Volatile fraction and aroma properties of microalgae Scenedesmus obliquus
}

Fração volátil e propriedades do aroma da microalga Scenedesmus obliquus

\author{
P. Lasta; K. R. Vieira; P. N. Pinheiro; R. Wagner; L. Q. Zepka; E. Jacob-Lopes* \\ Department of Food Science and Technology, Bioprocess Intensification Group, Federal University of Santa Maria, \\ 97105-900, Santa Maria-RS, Brazil \\ *ejacoblopes@gmail.com \\ (Trabalho avaliado e selecionado pela Comissão do III CTOCTA)
}

\begin{abstract}
Microalgae have great potential to become a new crop that could significantly impact the world's need for food in the 21 st century. Despite their potential as a food ingredient, microalgae need social acceptance as food. In addition, organoleptic traits, such as aroma, are key factors for humans to accept microalgae as part of their diet. In this sense, some requirements such as culture, species, and environmental conditions are extremely important for these microorganisms that are capable of producing a wide range of volatile organic compounds, such as alcohols, hydrocarbons, esters, aldehydes, terpenes, ketones, and lactones. Thus, the aim of the study was to characterize volatile organic compounds with an aroma descriptor from the microalgal biomass of Scenedesmus obliquus. The volatile compounds were isolated by solid-phase microextraction applied in the headspace, detected by gas chromatography, and differentiated by mass spectrometry (HS-SPME-GC/MS). The results showed that hexanol, 3-methyl-1-butanol, and 1-propanol were identified as the most abundant volatiles in the biomass of Scenedesmus obliquus.
\end{abstract}

Keywords: microalgae, volatile organic compounds, Scenedesmus obliquus.

As microalgas apresentam grande potencial para se tornarem uma nova cultura que poderá impactar significativamente a necessidade mundial de alimentos no século XXI. Apesar de seu potencial como ingrediente alimentar, as microalgas precisam de aceitação social como alimento. Além disso, traços organolépticos, como aroma, são fatores-chave para os humanos aceitarem as microalgas como parte de sua dieta. Nesse sentido, alguns requisitos como cultura, espécie e condições ambientais são extremamente importantes para esses microrganismos que são capazes de produzir uma vasta gama de compostos orgânicos voláteis, como álcoois, hidrocarbonetos, ésteres, aldeídos, terpenos, cetonas e lactonas. Assim, o objetivo do estudo foi caracterizar compostos orgânicos voláteis com um descritor de aroma da biomassa microalgal de Scenedesmus obliquus. Os compostos voláteis foram isolados por microextração em fase sólida aplicada no headspace, detectados por cromatografia gasosa e diferenciados por espectrometria de massa (HS-SPME-GC/MS). Os resultados mostraram que hexanol, 3-metil-1-butanol e 1-propanol foram identificados como os voláteis mais abundantes na biomassa de Scenedesmus obliquus.

Palavras-chave: microalgas, compostos orgânicos voláteis, Scenedesmus obliquus.

\section{INTRODUCTION}

Notoriously, the interest in functional foods has grown recently, due to the fact of presenting several physiological nutritional and energetic benefits, for example, antihypertensive, antioxidant, or anti-inflammatory. However, the functional components are obtained from foods enriched with a component capable of offering beneficial action to human health. In addition, it is required to be of natural origin, always preferable to synthetic. In a way, there is an increase in the search for new natural sources [1].

It is worth adding that algae and microalgae are potential sources of bioactive compounds, that is, are promising natural sources of several functional compounds and macroalgae are a source of functional food components. It is worth adding that not only the existence of a certain compound makes these microorganisms relevant, but also their diversity, the possibility of harvesting and cultivating them under different conditions and thus generating bioactive compounds [2].

In this context, microalgae are microscopic organisms, typically unicellular and eukaryotic, similar to plants. These microorganisms have the ability to fix $\mathrm{CO}_{2}$ in the presence of sunlight and catalyze its conversion into biomass for nutrition and growth [3]. In addition, microalgae have 
great potential for nutritional applications and can be integrated into a variety of foods. Whenever integrating microalgae in foods, the features of the aroma are an important factor to take into account. The aroma properties can be unpleasant in some applications or strongly pleasant in others; however, the little study is available on the taste of microalgae [4].

It is noteworthy that when microalgae are added to such products, the taste can be the satisfying factor in the consumer's preference for a particular product. Some requirements such as culture, species, and environmental conditions are extremely important for these microorganisms that are capable of producing a wide range of volatile organic compounds. Notoriously, the recognition of these compounds is of paramount importance due to their direct impacts on the aromatic properties of the final product enriched with microalgae biomass. Therefore, these identified compounds with aromatic characteristics belong to different classes, including hydrocarbons, aldehydes, alcohols, esters, ketones, lactones, and terpenes [5].

In addition, volatile compounds are characteristic of foods in which some of them can be perceived by men due to their aroma. They have strong leverage on consumer decision-making when accepting use or not a product. Consequently, if the product has a strong and offensive aroma, many consumers may not enjoy it. Already, smooth and fresh (natural) aromas increase the acceptance of a particular product. Additionally, these attributes can drastically influence the economy; therefore, it is important to point out to manufacturers that the aroma of their food products is characterized by analytical means to provide a basis for further optimization processes. Furthermore, the aromatic content of a food can prolong the nature of a product leading to the development of new products and being more acceptable to consumers [6]. Therefore, the aim of the study was to characterize volatile organic compounds with an aroma descriptor from the microalgal biomass of Scenedesmus obliquus.

\section{MATERIALS AND METHODS}

\subsection{Microalgae and Culture Media}

The study used axenic cultures from Scenedesmus obliquus. Stock cultures were propagated in solidified agar-agar $\left(20 \mathrm{~g} \mathrm{~L}^{-1}\right)$ containing synthetic BG-11 medium [7]. The incubation conditions used were: light intensity was constant $30 \mu \mathrm{mol} \mathrm{m}^{-2} \mathrm{~s}^{-1}$, temperature of $25^{\circ} \mathrm{C}$, and a photoperiod of $12 \mathrm{~h}$.

\subsection{Microalgae Biomass Production}

Biomass generation was performed according to Maroneze et al. (2016) [8], in photobioreactors operating in batches and fed with $2.0 \mathrm{~L}$ of synthetic BG-11 medium. The experimental conditions were as follows: isothermal reactor operating at a temperature of $26{ }^{\circ} \mathrm{C}$, photon flux density of $150 \mu \mathrm{mol} \mathrm{m}{ }^{-2} . \mathrm{s}^{-1}$, initial cell concentration of $100 \mathrm{mg} . \mathrm{L}^{-1}$, and continuous aeration of 1VVM (volume air per culture volume per minute) with the injection of air enriched with $15 \%$ carbon dioxide. The biomass was separated from the culture medium by centrifugation $\left(10,000 \mathrm{rpm}, 10^{\circ} \mathrm{C}, 10 \mathrm{~min}\right)$, the supernatant was discarded and the remaining biomass was frozen at $-18{ }^{\circ} \mathrm{C}$ for 24 hours. Soon after, it was lyophilized for $24 \mathrm{~h}$ at $-50^{\circ} \mathrm{C}$ above $-175 \mu \mathrm{m} \mathrm{Hg}$ and finally stored at $-18^{\circ} \mathrm{C}$ until analysis.

\subsection{Extraction, Identification and Quantification of Volatile Compounds}

\subsubsection{Isolation of The Volatile Organic Compounds}

Volatile compounds were separated from the matrix using headspace solid-phase microextraction (HS-SPME) divinylbenzene/Carboxen/polydimethylsiloxane (DVB/Car/ PDMS) fiber $(50 / 30 \mu \mathrm{m}$ film thickness $\times 20 \mathrm{~mm}$; Supelco, Bellefonte, PA) for gas 
chromatography-mass spectrometry (GC-MS) analysis [9]. An aliquot of $0.2 \pm 0.02 \mathrm{~g}$ of the microalgal biomass was inserted into a $20 \mathrm{~mL}$ screw-capped bottle with a PTFE/silicone septum cap (Supelco, Bellafonte, PA). The SPME fiber was exposed to the headspace of the vial for 60 $\min$ at $40{ }^{\circ} \mathrm{C}$. Subsequently, the fiber was removed from the bottle and subjected to chromatographic analysis [5].

\subsubsection{GC/MS Analysis}

Volatile compounds were detected according to Santos et al. (2016) [9] by gas chromatography coupled to a mass spectrometer (QP 2010 Plus, Shimadzu, Kyoto, Japan). The fiber was thermally desorbed for $15 \mathrm{~min}$ in the split/splitless injector, operating in splitless mode (splitter $1.0 \mathrm{~min}$ off) at $250{ }^{\circ} \mathrm{C}$. Helium was used as carrier gas at a constant flow rate of $1.6 \mathrm{~mL} \cdot \mathrm{min}^{-1}$. Analytes were separated in a DB-Wax fused silica capillary column, $60 \mathrm{~m}$ long, $0.25 \mathrm{~mm}$ i.d., and $0.25 \mu \mathrm{m}$ film thickness (Chrompack Wax 52-CB). The initial column temperature was set at $35^{\circ} \mathrm{C}$ for $5 \mathrm{~min}$, followed by a linear increase of $5{ }^{\circ} \mathrm{C} \mathrm{min}^{-1}$ to $220^{\circ} \mathrm{C}$, and this temperature was maintained for 5 $\mathrm{min}$. The MS detector was operated in the $+70 \mathrm{eV}$ electron impact ionization mode, and the mass spectra were obtained by a scanning range of $\mathrm{m} / \mathrm{z} 35$ to 350 . The identification of volatile organic compounds was carried out from the experimental comparison of the MS spectra with those provided by the computer library (NIST MS Search). In addition, the linear retention index (LRI) was calculated for each volatile compound using the retention times of a standard mixture from the homologous paraffin series (C6-C24) to aid in identification [10]. The sample and the standard mixture were injected both separately and together to obtain the experimental LRI and mass spectra values for the purpose of compound identification by directed comparison. Finally, analytes were quantified based on relative peak areas.

\section{RESULTS AND DISCUSSION}

In this study, 23 different volatile compounds described in the Scenedesmus obliquus microalgae were detected, referent to a variety of chemical classes: alcohols, aldehydes, terpenes, lactones, esters, and hydrocarbons. Figure 1 shows the percentage of these aromatic compounds separated by the functional group detected in the Scenedesmus obliquus microalgae. In which we observed that approximately $60 \%$ of the detected compounds are from the alcohol class, $18 \%$ from the aldehyde class, and $14 \%$ from the terpene class.

It is worth adding that alcohol compounds have high demand in the market as fuels and industrial solvents. Currently, ethanol is one of the most used alcohols, but on the other hand, other alcohols are receiving attention, for example, propanol, 1-butanol, and 3-methyl 1-butanol. Propanol can be applied as bulk material in synthesis, flavoring compound, cosmetic ingredient, and sanitizing agent [11].

On the other hand, branched-chain aldehyde compounds such as 3-methyl butanal are made up of strong aromas. For some food products, these compounds are critical to flavor. Additionally, these compounds are detected as malty, similar to chocolate. It is worth adding that a relevant process that leads to the formation of compounds such as 3-methyl butanal is the heat-induced non-enzymatic Strecker degradation of amino groups with sugar reducing fractions [12].

Finally, terpenes are plant components coming from different combinations of $\mathrm{C} 5$ isoprene subunits and have pharmacological and medicinal properties. Furthermore, the volatile and semivolatile fractions of terpenoids can be classified into two classes, own to their number of carbon atoms in their structure [13]. 


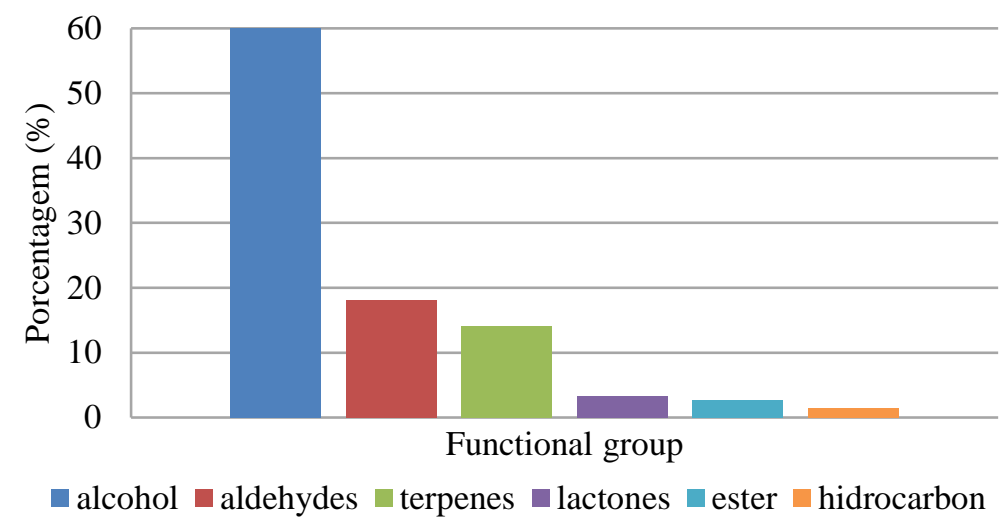

Figure 1: Percentage of aromatic compounds separated by functional group detected in Scenedesmus obliquus microalgae.

In Table 1, the results show that hexanol (20.22 \%), 3-methyl-1-butanol (13.75\%) and 1propanol (11.28 \%) were identified as the most abundant volatiles in Scenedesmus obliquus biomass. The literature describes these compounds as, for example, 1-propanol has a pungent alcohol aroma; 3-methyl-1-butanol with the aroma of whiskey, malt, burnt; and the hexanol compound aroma of resin, flower, green [10].

Table 1: Aromatic compounds detected from Scenedesmus obliquos.

\begin{tabular}{lllll}
\hline Peak & LRI-DBWax & Compounds & \% $(*)$ & Descriptor \\
\hline 1 & 888 & Butanal & 0.58 & pungent, green \\
2 & 1.001 & Pentanal & 4.32 & almond, malt, pungent \\
3 & 1.059 & Toluene & 1.49 & paint \\
4 & 1.073 & 1-Propanol & 11.28 & alcohol, pungent \\
5 & 1.110 & Hexanal & 6.27 & grass, tallow, fat \\
6 & 1.173 & 1-Butanol & 5.78 & medicine, fruit \\
7 & 1.208 & Limonene & 0.58 & lemon, orange \\
8 & 1.224 & 1,8-Cineole & 0.27 & mint, sweet \\
9 & 1.230 & 3-Methyl-1-butanol & 13.75 & whiskey, malt, burnt \\
10 & 1.235 & 2-Hexenal & 6.61 & apple, green \\
11 & 1.250 & Ethyl hexanoate & 2.64 & apple peel, fruit \\
12 & 1.269 & 1-Pentanol & 7.66 & fruit \\
13 & 1.298 & Octanal & 0.32 & fat, soap, lemon, green \\
14 & 1.371 & Hexanol & 20.22 & resin, flower, green \\
15 & 1.479 & 1-Heptanol & 1.58 & herb \\
16 & 1.621 & $\beta$-Caryophyllene & 1.13 & wood, spice \\
17 & 1.650 & $\beta$-Cyclocitral & 1.85 & mint \\
18 & 1.663 & Butyrolactone & 3.39 & caramel, sweet \\
19 & 1.675 & Safranal & 1.97 & herb, sweet \\
20 & 1.775 & L-Carvone & 0.15 & mint, basil, fennel \\
21 & 1.849 & $\alpha$-Ionone & 2.23 & wood, violet \\
22 & 1.893 & trans- $\beta$-Ionone & 3.83 & seaweed, violet, flower, \\
& & & & raspberry \\
23 & 1.948 & $\beta$-ionone epoxide & 2.11 & fruit, sweet, wood \\
\hline$(*)$ & & & & \\
\hline
\end{tabular}

(*) concentration based on percentage of area 
In addition, the 1-propanol compound is an alcohol that can be used as a substitute for gasoline. It is currently used as a multipurpose solvent in a variety of industrial products, such as paints, cleaning products, and cosmetics [14]. On the other hand, the compound 3-methyl-1-butanol is also alcohol with the potential to replace fuels, being also used as a precursor for the synthesis of several chemical products, such as isoamyl acetate [15]. Finally, among the main compounds in this study, the compound hexanol is also alcohol that can be used to replace fuels [16].

\section{CONCLUSION}

Recently, there is great interest in the applicability of volatile organic compounds that can extend the shelf life of certain food products with natural properties. It is believed that these compounds will create an opportunity to decrease the use of chemical preservatives in functional foods.

Therefore, this study demonstrated the relevance of the volatile compounds hexanol, 3-methyl1-butanol, and 1-propanol being major compounds of the microalgae Scenedesmus obliquus. Thus, demonstrating the use of natural sources that can potentially be used for the food industry.

\section{ACKNOWLEDGEMENTS}

The authors are grateful to the National Academic Cooperation Program PROCAD/CAPES, National Counsel of Technological, Scientific Development (CNPq), and the Federal University of Santa Maria.

\section{REFERENCES}

1. Herrero M, Cifuentes A, Ibañez E. Sub-and supercritical fluid extraction of functional ingredients from different natural sources: Plants, food-by-products, algae and microalgae: A review. Food Chem. 2006;98(1):136-48. doi: 10.1016/j.foodchem.2005.05.058

2. Plaza M, Santoyo S, Jaime L, Reina GGB, Herrero M, Señoráns FJ, et al. Screening for bioactive compounds from algae. J Pharm Biomed Anal. 2010 Jan;51(2):450-5. doi: 10.1016/j.jpba.2009.03.016

3. Achyuthan KE, Harper JC, Manginell RP, Moorman MW. Volatile metabolites emission by in vivo microalgae - an overlooked opportunity? Metabolites. 2017 Jul;7(3):39. doi: 10.3390/metabo7030039

4. Van Durme J, Goiris K, De Winne A, De Cooman L, Muylaert K. Evaluation of the volatile composition and sensory properties of five species of microalgae. J Agric Food Chem. 2013 Oct; 61(46):10881-90. doi: $10.1021 / \mathrm{jf} 403112 \mathrm{k}$

5. Hosoglu MI. Aroma characterization of five microalgae species using solid-phase microextraction and gas chromatography-mass spectrometry/olfactometry. Food Chem. 2018 Feb;240:1210-18. doi: 10.1016/j.foodchem.2017.08.052

6. Lubes G, Goodarzi M. Analysis of volatile compounds by advanced analytical techniques and multivariate chemometrics. Chem Rev. 2017 Mar;117(9):6399-422. doi: 10.1021/acs.chemrev.6b00698

7. Rippka R, Derulles J, Watrerbury JB, Herdman M, Stainer RY. Generic assignments, strain histories and properties of pure cultures of cyanobacteria. J Gen Microbiol. 1979 Mar;111(1):1-61. doi: 10.1099/00221287-111-1-1

8. Maroneze MM, Siqueira SF, Vendruscolo RG, Wagner R, De Menezes CR, Zepka LQ, et al. The role of photoperiods on photobioreactors - A potential strategy to reduce costs. Bioresour Technol. 2016 Nov;219:493-9. doi: 10.1016/j.biortech.2016.08.003

9. Santos AB, Fernandes AS, Wagner R, Jacob-Lopes E, Zepka LQ. Biogeneration of volatile organic compounds produced by Phormidium autumnale in heterotrophic bioreactor. J Appl Phycol. 2016 Nov;28(3):1561-70. doi: 10.1007/s10811-015-0740-0

10. Flavornet and human odor space [Internet]. Geneva (NY): Acree T, Heinrich A; 1984 - 2017 [cited 2021]. Available from: http://www.flavornet.org/f_kovats.html

11. Hegde S, Lodge JS, Trabold TA. Characteristics of food processing wastes and their use in sustainable alcohol production. Renew Sustain Energy Rev. 2018 Jan;81(Part 1):510-23. doi: 10.1016/j.rser.2017.07.012 
12. Smit BA, Engels WJ, Smit G. Branched chain aldehydes: production and breakdown pathways and relevance for flavour in foods. Appl Microbiol Biotechnol. 2009 Jan;81(6):987-99. doi: 10.1007/s00253-008-1758-x

13. Gaggiotti S, Palmieri S, Della Pelle F, Sergi M, Cichelli A, Mascini M, et al. Piezoelectric peptidehpDNA based electronic nose for he detection of terpenes; Evaluation of the aroma profile in different Cannabis sativa L. (hemp) samples. Sensors and Actuators B: Chem. 2020 Apr;308:127697. doi: 10.1016/j.snb.2020.127697

14. Shen CR, Liao JC. Metabolic engineering of Escherichia coli for 1-butanol and 1-propanol production via the keto-acid pathways. Metab Eng. 2008 Nov;10(6):312-20. doi: 10.1016/j.ymben.2008.08.001

15. Connor MR, Liao JC. Engineering of an Escherichia coli strain for the production of 3-methyl-1butanol. Appl Environ Microbiol. 2008 Sep;74(18):5769-75. doi: 10.1128/AEM.00468-08

16. Phillips JR, Atiyeh HK, Tanner RS, Torres JR, Saxena J, Wilkins MR, et al. Butanol and hexanol production in Clostridium carboxidivorans syngas fermentation: medium development and culture techniques. Bioresour Technol. 2015 Aug;190:114-21. doi: 10.1016/j.biortech.2015.04.043 